УДК 553.98:551.8:551.734.3:551.243.31(235.223)

\title{
ПАЛЕОГЕОГРАФИЧЕСКИЕ, ЛИТОЛОГО-ГЕОХИМИЧЕСКИЕ ОСОБЕННОСТИ И БИТУМИНОЗНОСТЬ ЖИВЕТСКИХ ОТЛОЖЕНИЙ СРЕДНЕГО ДЕВОНА АЛТАЕ-САЯНСКОЙ СКЛАДЧАТОЙ ОБЛАСТИ
}

\author{
Шаминова Марина Ивановна1, \\ mshaminova@mail.ru
}

\author{
Рычкова Ирина Владимировна ${ }^{1}$, \\ irina.rychkova@mail.ru \\ Саар Кристина Николаевна², \\ saar.kris@mail.ru \\ 1 Национальный исследовательский Томский политехнический университет, \\ Россия, 634050, г. Томск, пр. Ленина, 30. \\ 2 АО «Якутскгеология» Алданское ОП, \\ Россия, 677009, г. Якутск, ул. Кальвицына, 24.
}

\begin{abstract}
Актуальность исследования обусловлена недостаточной изученностью палеозойских нефртегазоносных отложений Западной Сибири и сопряженной с ней Алтае-Саянской складчатой области, хотя на этой территории недавно открыты новые месторождения нефти и газоконденсата. Палеозойские отложения являются высокоперспективным объектом для открытия месторождений углеводородов. Результаты палеогеографических и литолого-геохимических исследований изучаемого региона могут существенно повлиять на реконструкцию палеообстановок, благоприятных для генерации и аккумуляции УВ, а также оценку перспектив нефтегазоносности палеозойских отложений и выявление нетрадиционных коллекторов.

объекты: карбонатные породы живетского яруса среднего девона, обнажающиеся в карьерах Камень и Подломск (Томская область), Лебедянском карьере (Кемеровская область), в районах оз. Фыркал и Ошколь, а также западнее оз. Тус (Северная Хакасия).

Цель: палеогеографическая реконструкция обстановок осадконакопления, благоприятных для нефте- и газонакопления, а также выявление и оценка перспектив нефтегазоносности палеозойских отложений в породах палеозойского фундамента.

Методы: литолого-петрографические, палеонтологические, палеогеографические, литогеохимические (метод рентгеноспектрального анализа, люминесцентно-микроскопический, растровой электронной микроскопии, ICP-MS).

Результаты. Авторами впервые установлены признаки нефтегазоносности среднедевонских отложений в Томской области (карьеры Камень и Подломский), в Кемеровской области (Лебедянский карьер), в Северной Хакасии (районы оз. Фыркал и Ошколь, а также западнее оз. Тус). В результате палеонтологических и геохимических исследований выявлены особенности палеосреды осадконакопления, благоприятной для аккумуляции ОВ, захоронения и генерации УВ. Среди изученных отложений выделены петротипы: баундстоун, рудстоун, фрлаутстоун, пакстоун, вакстоун и мадстоун, которые претерпели интенсивные постседиментационные преобразования, что существенно повлияло на их коллекторские свойства. Люминесцентномикроскопические исследования позволили установить фракты интенсивной фрюидомиграции в изученных районах и выделить потенциальные коллекторы. Выяснено, что наибольшее количество битумоидов фриксируется в рифогенных известняках-баундстоун. Этот петротип обладает высоким коллекторским потенциалом, т. к. слагающие его кораллы обладают хорошими для этого качествами - кавернозностью и биопустотностью.
\end{abstract}

\section{Ключевые слова:}

Алтае-Саянская складчатая область, живетские отложения, средний девон, битуминозность, петротипы.

\section{Введение}

Исследование палеозоя Алтае-Саянской складчатой области (АССО) имеет достаточно длинную историю. Однако в настоящее время возник повышенный интерес к изучению нетрадиционных коллекторов на данной территории [1-3]. Проведение палеореконструкций и решение вопросов, связанных с условиями их седиментогенеза, отразится на оценке перспектив генерации и аккумуляции углеводородов (УВ) глубоких горизонтов молодой эпигерцинской Западно-Сибирской платформы.

Объектом исследования являются карбонатные отложения (живет, средний девон), распространенные в ACCO (карьеры Камень и Подломский в Томской области, карьер Лебедянский в Кемеровской области, обнажения в районах оз. Фыркал, Ошколь, западнее о3. Тус в Северной Хакасии).
Изученные отложения представляют собой локальные выходы живетского яруса среднего девона в пределах АCСО [4]. Это позволяет установить продолжение складчатого фундамента и сделать выводы об специфичности их формирования и битуминозности [5-8].

\section{Литологическая характеристика отложений}

Породы живетского яруса в изучаемых районах представлены преимущественно органогенными и биохемогенными известняками, окраска которых изменяется в светло-серых тонах. Характерными структурами являются биоморфные. Текстуры неоднородные, на отдельных участках пятнистые. В породах отмечается примесь терригенного материала алевритовой размерности. 
Известняки подвергнуты интенсивным вторичным преобразованиям, среди которых преобладает перекристаллизация с укрупнением зерен, кальцитизация и доломитизация по трещинам и кавернам. Часто отмечается выщелачивание, которое проявляется в возникновении пустот и полостей, заполненных органическим битуминозным веществом. Среди изученных карбонатных пород было выделено несколько петротипов, согласно классификации Р.Х. Данхема, А. Эмбри и Дж. Кловена [9].

В карьерах Камень и Подломский были выделены петротипы: баундстоун, пакстоун, мадстоун. В карьере Лебедянский: баундстоун, рудстоун. В районе оз. Фыркал выделены петротипы: флаутстоун, пакстоун, вакстоун. Среди известняков в районе оз. Ошколь и западнее оз. Тус были выделены три петротипа: пакстоун, вакстоун, мадстоун.

Баундстоун - известняк автохтонный, рифогенный, на отдельных участках перекристаллизованный (с укрупнением зерен). Этот известняк биогенный, формируется из компонентов организмов в положении роста, с сохранением органогенного каркаса и полостей между скелетами, выполненных микрозернистым кальцитом, обломками организмов и их смесью. В породах Лебедянского карьеpa встречаются ископаемые остатки: строматопораты, криноидеи, кораллы-табуляты (Thamnopora cervicornis B., Thamnopora sp., Pachyfavosites polymorphus G.), кораллыругозы Thamnophyllum sp. (рис. 1), Heliophyllum sp., Pseudomicroplasma fongi Y.), трилобиты (Phacops (Phacops) altaicus Т.), брахиоподы (Acrospirifer cheehiel K.).

Возраст отложений датирован как живетский по фауне брахиопод и кораллов [10]. В баундстоунах кроме скелетной составляющей присутствовали фито- и зоопланктон, преобразованные в дальнейшем в сингенетично-битуминозное вещество.

Формирование подобной рифогенной постройки проходило на участке теплого, нормально-соленого моря при хорошей освещенности, в некотором удалении от береговой линии, без привноса терригенного материала, о чем свидетельствуют стенобионтные кораллы. Данная рифовая постройка может служить хорошим коллектором для мигрирующих углеводородов, т. к. слагающие ее кораллы обладают хорошим потенциальным для этого качеством - кавернозностью и биопустотностью (рис. 2).

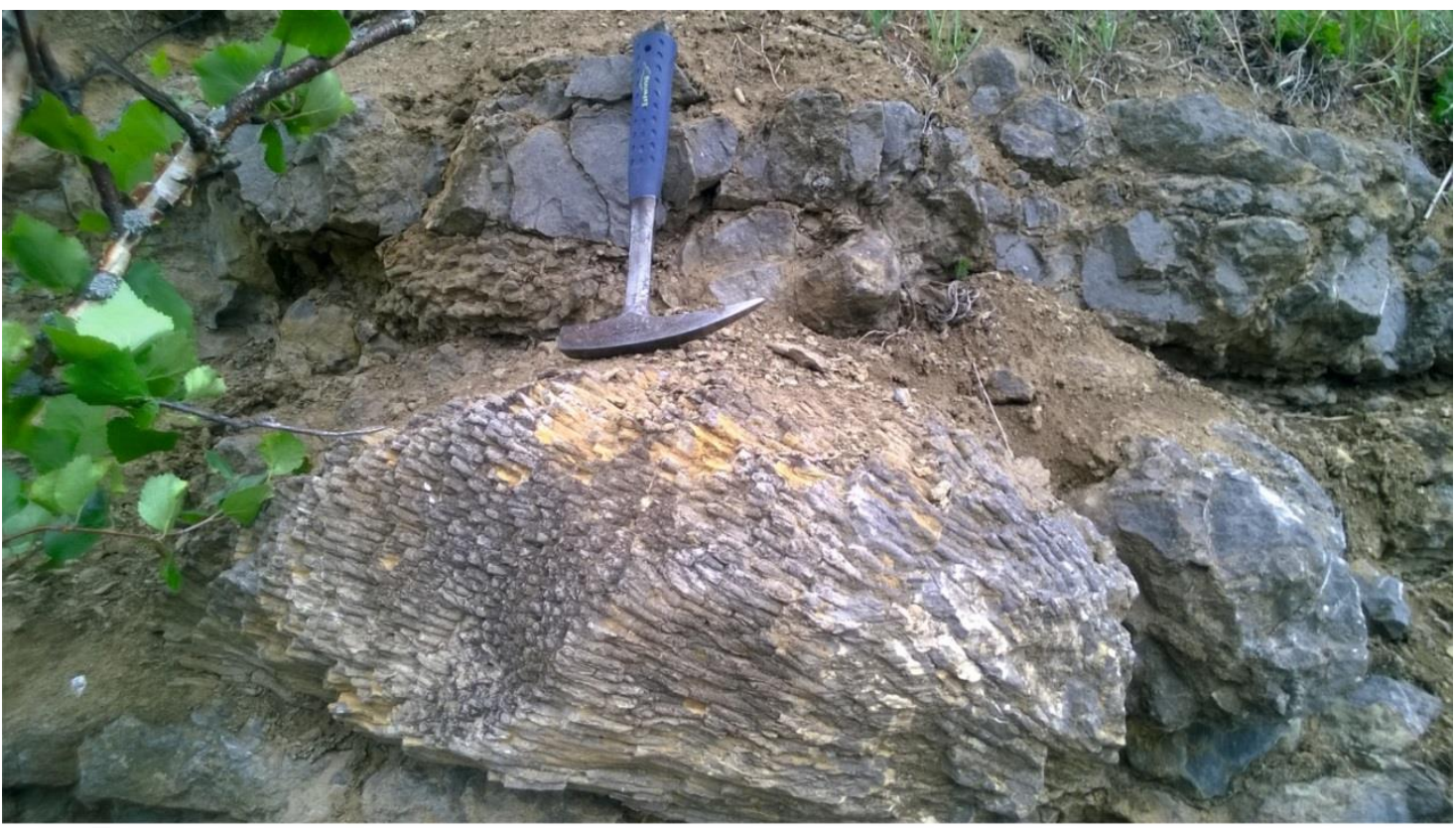

Рис. 1. Рифогенный известняк из карьера Лебедянский, коралль Thaтпорhyllum sp.

Fig. 1. Rifogenic limestone of the Lebedyansky quarry, corals Thamnophyllum sp.

Рудстоун - аллохтонный известняк песчанистый, детритовый, плотный, серый. Данные известняки содержат более $10 \%$ зерен размером более 2 мм, с плотной упаковкой компонентов. В породах встречаются обломки брахиопод, криноидей и мшанок. Известняки песчанистые детритовые плотные серые.

Флаутстоун - это аллохтонный известняк, содержащий в себе кальцитовые зерна (преимущественно их размер составляет $0,01 \ldots 0,24$ мм). Иногда в породе встречаются зерна более крупные, размер которых достигает 4,7 мм, но таких отдельных обломков очень мало, и они не превышают $10 \%$ от всей массы породы. Процесс выщелачивания в известняках обуслав- ливает появление пор и каверн, которые имеют размеры до 3,85 мм. В известняках имеются трещинки, которые заполнены битуминозным веществом. Среди особенностей этого петротипа выделяется наличие стилолитовых швов.

Пакстоун - это аллохтонный известняк, на 80-85\% сложен органическими остатками. Практически все они представляют собой округлые биогенные образования в виде комочков, сферической формы - онколиты, размер которых варьирует $0,02 \ldots 0,16$ мм. Петротип характеризуется большим содержанием пор и каверн, размеры которых $0,09 \ldots$ 3,6 мм. Морфология пустот неправильная, щелевидная, заливообразная. 


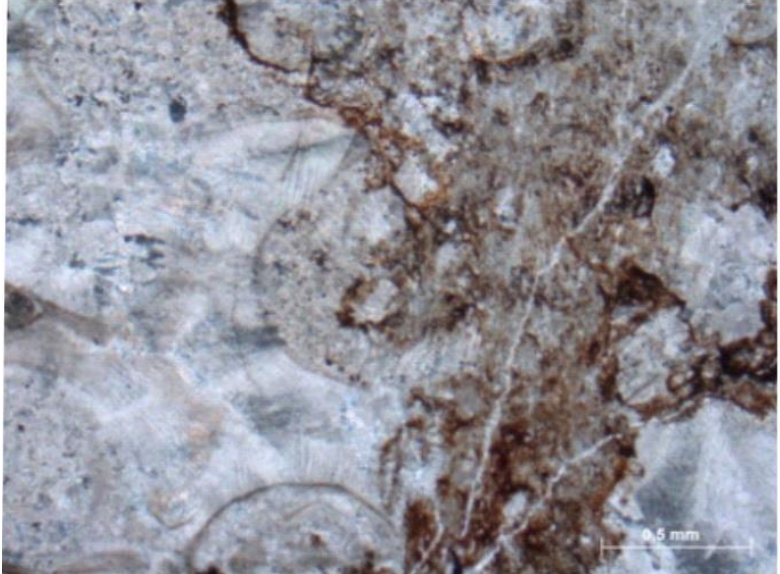

$\mathrm{a} / \mathrm{a}$

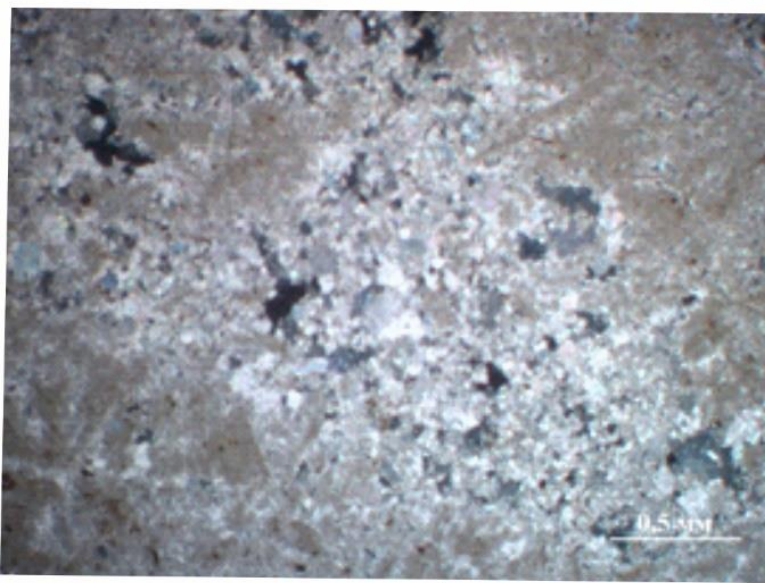

$\mathrm{B} / \mathrm{C}$

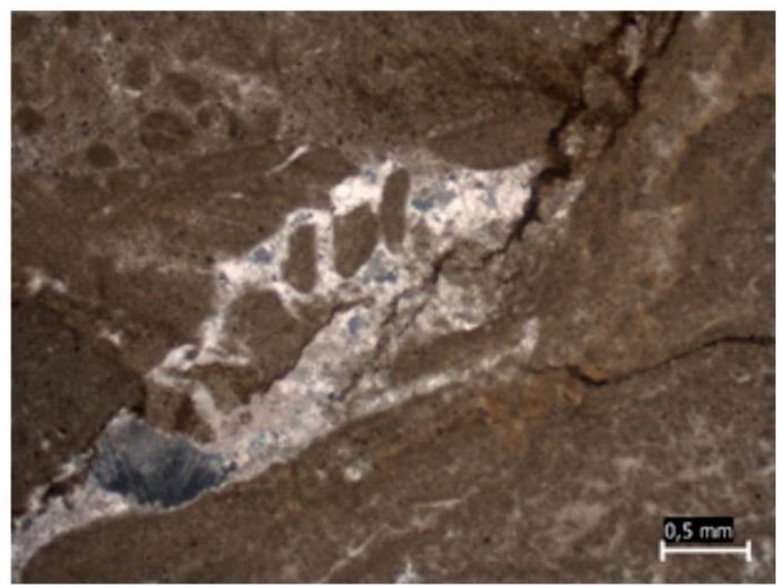

д/e

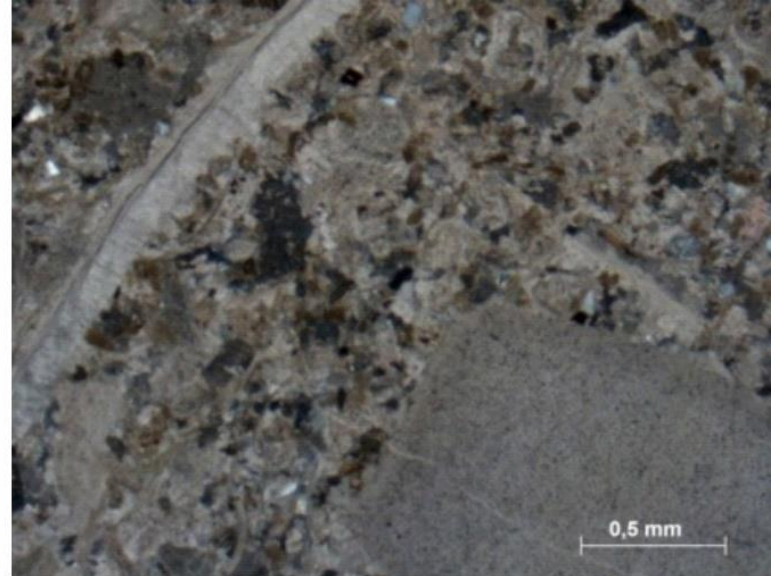

$\sigma / b$

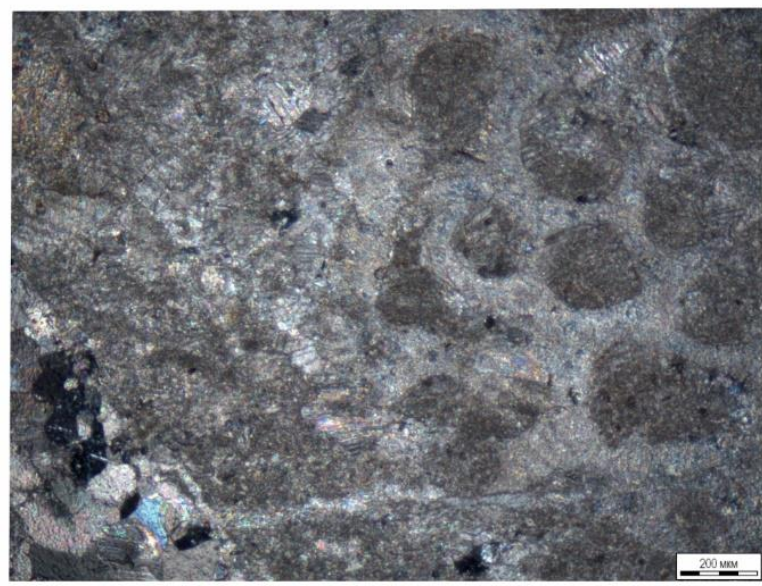

$\Gamma / \mathrm{d}$

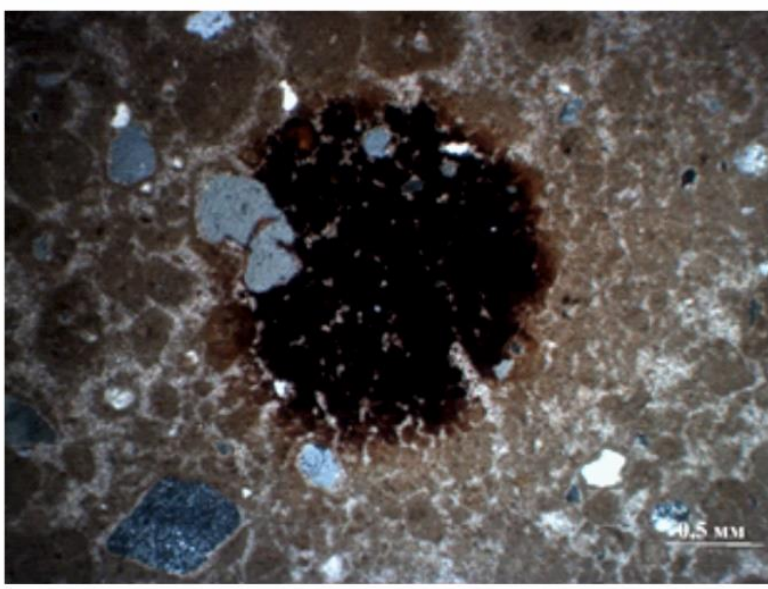

$\mathrm{e} / \mathrm{f}$

Puс. 2. Вылеленные петротипь:: а) баундстоун (карьер Лебедянский); б) рудстоун (карьер Лебедянский); в) флаутстоун (р-н оз. Фыркал); г) пакстоун (карьер Камень); д) вакстоун (р-н оз. Фыркал); е) мадстоун (р-н оз. Ошколь)

Fig. 2. Highlighted petrotypes: a) boundstone (Lebedyansky quarry); b) rudstone (Lebedyansky quarry); c) floatstone (lake Fyrkal area); d) packstone (Kamen quarry); e) wackstone (lake Fyrkal area); f) madstone (lake Oshkol area)

На стенках пор и подводящих к ним трещинах отмечается битуминозное вещество. В дальнейшем, в процессе катагенеза, поры выщелачивания были заполнены карбонатами. Зерна кальцита в порах и кавернах имеют размеры до 0,49 мм, а доломита 0,07...0,4 мм. Кроме того, породы, относящиеся к пакстоуну, интенсивно окремнены. Кремнистые минералы (халцедон и кварц) отмечаются в зёрнах с размерами 0,03...0,17 мм. Отложения могли формироваться в зоне прибрежного мелководья, где интенсивно проявляются процессы волнений и течений. 
Вакстоун - аллохтонный известняк, сложенный сгустками микрозернистого материала (размер частиц $0,06 \ldots 0,4$ мм) различных форм - от неправильной до сферической и овальной. Породы сложены преимущественно кальцитом. Катагенетические преобразования проявились в доломитизации открытых трещин, причем этот процесс проходил позднее поступления битуминозного вещества. Размеры зерен доломита не превышают 0,95 мм. Кроме этого, в породах вакстоуна фиксируется доломитизация остатков раковин безпозвоночных (остракод и фораминифер). Для этих известняков характерна послойная битуминизация. Отмечаются четкие контакты слойков, обогащенных битуминозным $\mathrm{OB}$, переслаивающихся с комковатосгустковой микрозернистой массой. В породах практически отсутствуют поры и каверны. Данный тип известняка характеризует обстановки открытых платформ, относительно заглубленной части шельфа ниже базиса действия волнового воздействия.

Мадстоун - аллохтонный известняк, основную массу которого составляет микрозернистый кальцит с размером зерен до 0,23 мм, сцементированный гидрослюдами. В породах иногда встречаются измененные обломки кварца, размер которых варьирует $0,02 \ldots 0,88$ мм. Обломки кварца корродированы и регенерированы, толщина каемок до 0,01 мм. Кроме того, в породе отмечаются обломки мелкозернистого алевролита. Пористость и кавернозность в этих породах не наблюдается. Петротип характеризуется наличием стилолитовых забитуминизированных швов шириной до 0,04 мм. В породах присутствуют мелкие трещинки, которые тоже заполнены битуминозным веществом, а большие рукавообразные трещины заполнены гидрослюдистым цементом или микрозернистым кальцитом. В целом битуминозное вещество рассредоточено по всей породе неравномерно. Из органогенных остатков встречаются фораминиферы, гастроподы и колонии мшанок. Мадстоун мог формироваться в местах штормового воздействия.

\section{Постседиментационные преобразования}

и их влияние на коллекторские свойства

Изученные породы подверглись интенсивным постседиментационным преобразованиям: перекристаллизации, выщелачиванию, доломитизации, микростилолитизации, окремнению (рис. 3), что в целом привело к разуплотнению пород. Именно на таких участках отмечается повышенная битуминозность.

В породах, в которых присутствует примесь кремнистого и глинистого материала, отмечаются следующие типы перекристаллизации: рассеянный, прожилковый, кружевной, пятнистый. Катагенетические преобразования также изменили первоначальный облик породы, о котором можно судить только по реликтовым структурным признакам.

В единичных случаях в породах зафиксирована перекристаллизация с уменьшением зерен (микритизация), которая чаще всего отмечается в баундстоунах.
Неравномерное катагенетическое выщелачивание в известняках привело к увеличению пористости и проницаемости пород, что оказало достаточно сильное влияние на формирование их фильтрационноемкостных свойств.

Циркуляция в известняках поровых вод привела к формированию пустот различных форм и размеров. Морфология пор преимущественно неправильная, изометричная, заливообразная. Иногда пустоты выщелачивания приводят к раздувам открытых трещин, которые в последствии могут быть заполнены аутигенными минералами (доломитом) и битуминозным веществом. Размеры пор изменяются от 0,01 до 4,0 мM.

Катагенетическая доломитизация распределяется неравномерно в матриксе породы. Обычно замещаются сначала реликтовые компоненты, а затем доломит появляется на участках постдиагенетической перекристаллизации и окремнения, а также отмечается приуроченность ромбоэдрических зерен доломита, обладающих нередко зональным строением, к наиболее проницаемым участкам (трещинам, кавернам, микростилолитовым швам). Иногда в зернах доломита фиксируются реликтовый кальцит.

Кислые подземные воды способствовали окремнению карбонатных пород, при этом отмечается заполнение кремнеземом отдельных интерстиций, пустот выщелачивания с образованием преимущественно халцедона. Изредка халцедон замещает крупные кристаллы кальцита с образованием радиально-лучистого агрегата. Еще реже в пустотах отмечаются новообразованные зерна кварца с хорошей кристаллографической огранкой. Размеры зерен кремнистых минералов изменяются от сотых до десятых долей мм. Окремнение, как правило, неравномерное, пятнистое.

В породах часто развита разнонаправленная трещиноватость. Кроме этого, почти во всех образцах фиксируются единичные микростилолиты, швы которых заполнены органоминеральной смесью, состоящей из глинистого и битуминозного вещества. Максимальная ширина швов до 0,06 мм. Такие текстурные признаки характерны для известняков, подвергшихся растворению под давлением, в результате чего швы микростилолитов в дальнейшем обогащаются битуминозными компонентами.

\section{Люминесцентно-микроскопический анализ} битумоидов и органического вещества

В изученных в ультрафиолетовом свете (УФ) карбонатных отложениях живетского возраста АCСО было обнаружено битуминозное вещество (рис. 4). Практически во всех образцах отмечаются следы миграции битумоидов, что свидетельствует о проявлении в разрезе процессов флюидомиграции. Содержание битумоидов и их состав меняется по петротипам $[11,12]$. Наибольшее количество битумоидов зафиксировано в рифогенных известняках баундстоун (карьеры Камень, Подломский, Лебедянский). Минимальное содержание битумоидов отмечается в петротипе мадстоун района оз. Фыркал. 


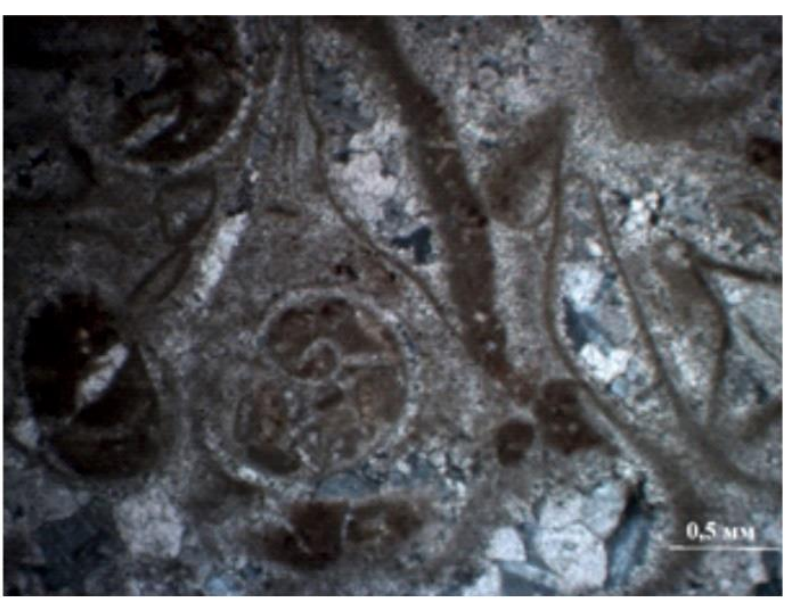

$\mathrm{a} / \mathrm{a}$

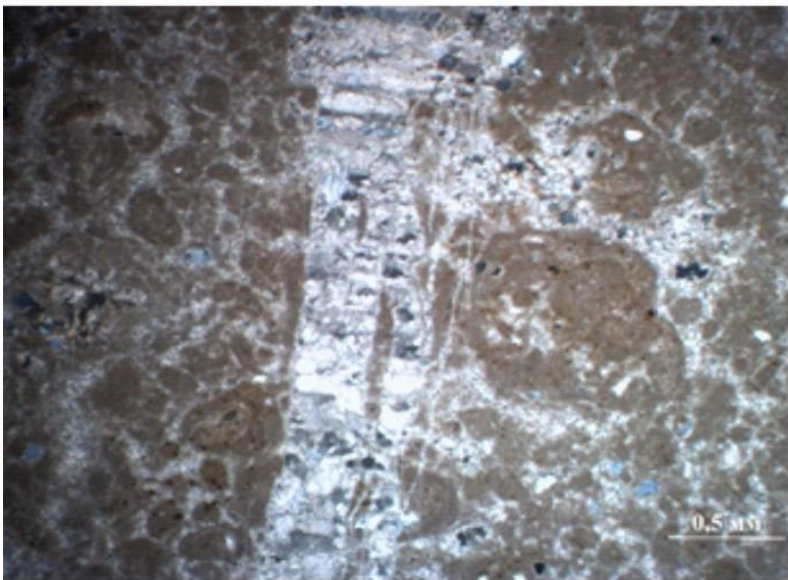

$\mathrm{B} / \mathrm{c}$

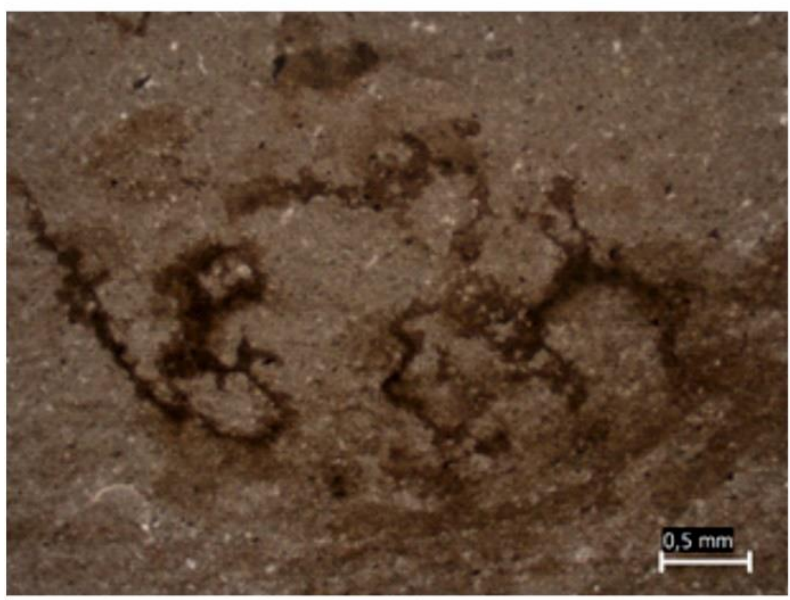

д/е

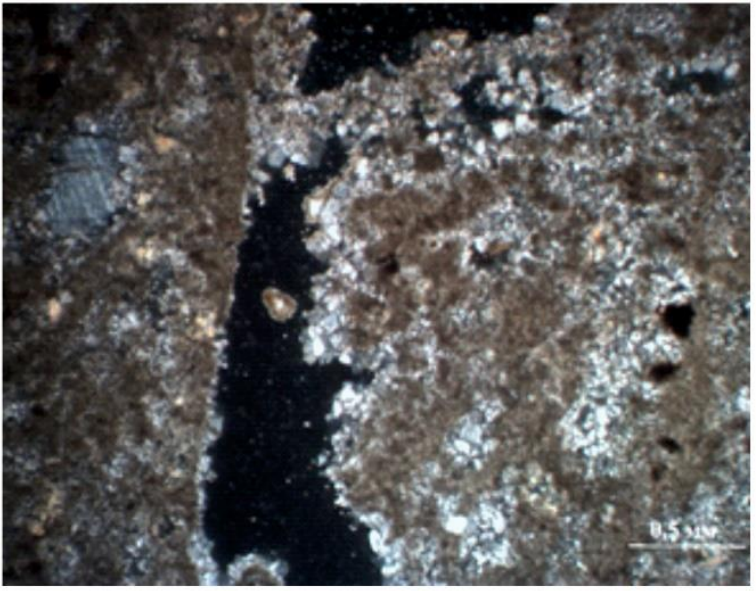

$6 / \mathrm{b}$

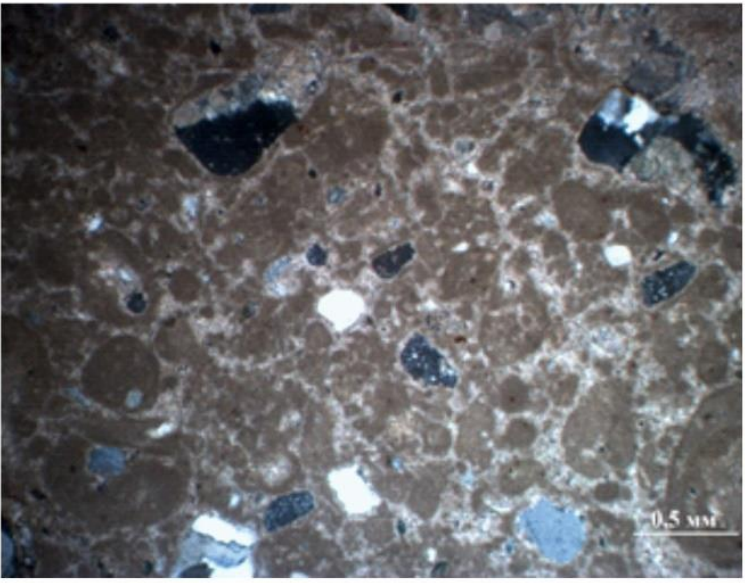

$\Gamma / \mathrm{d}$

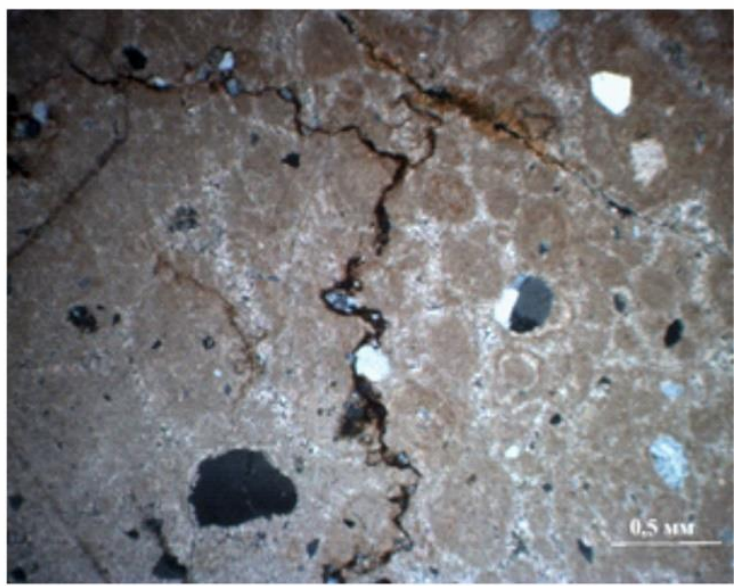

$\mathrm{e} / \mathrm{f}$

Pис. 3. Постседиментационные преобразования в образцах р-на оз. Фыркал (николи скрещенные): а) перекристаллизация пустотных пространств и раковин; б) пустоты выщелачивания неправильной формы; в) доломитизация широких рукавообразных трещин; г) процесс окремнения, образование отдельных зерен квариа; д, е) микростилолитовые швы (р-н оз. Ошколь)

Fig. 3. Postsedimentary transformations in the samples of the lake Fyrkal area (Nicolas crossed): a) recrystallization of voids and cavities; b) leaching voids of irregular shape; $c$ ) dolomitization of wide sleeve-like cracks; d) silicification, formation of individual quartz grains; $e, f$ ) microstylolite seams (lake Oshkol area) 


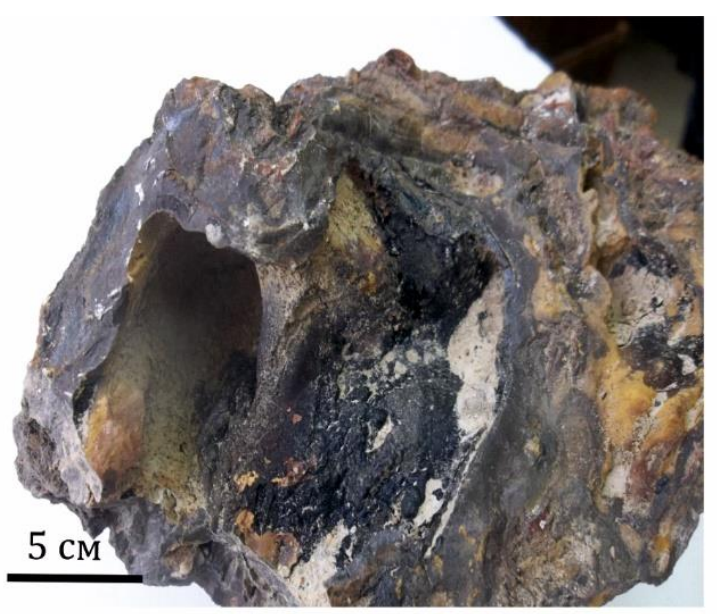

$\mathrm{a} / \mathrm{a}$

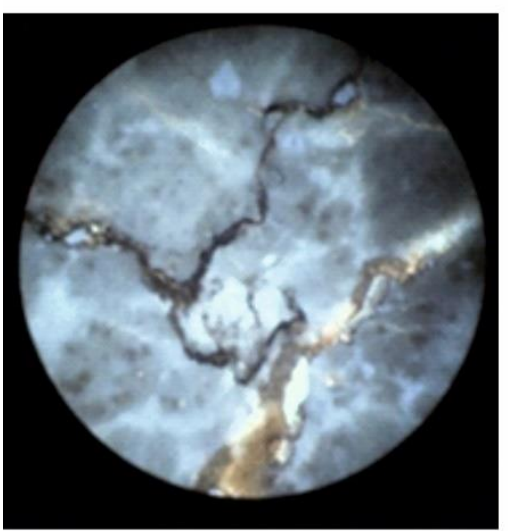

$\mathrm{B} / \mathrm{c}$

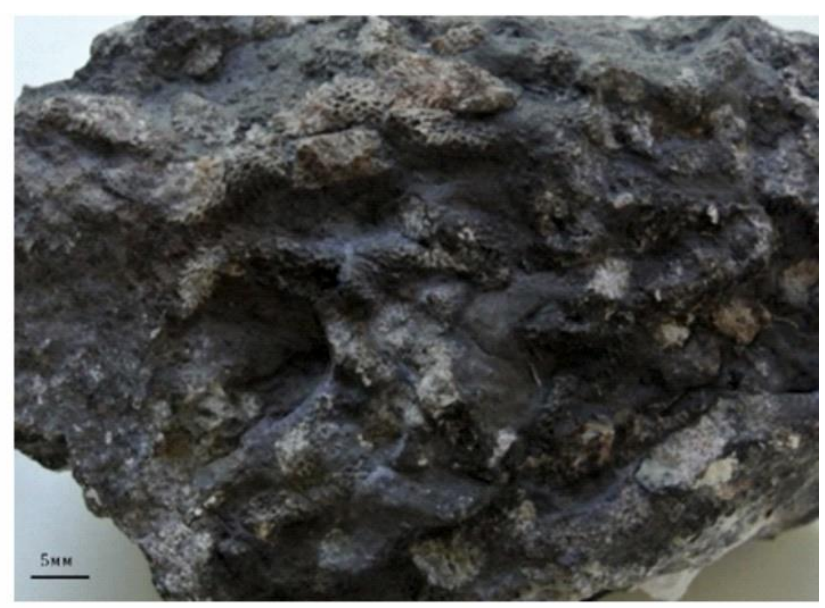

$6 / \mathrm{b}$

Pис. 4. Породы, пропитанные битуминозным веществом: а) образеи с выделениями твердых битумов (карьер Камень); б) коралловый известняк (баундстоун), пропитанный битуминозным веществом (карьер Лебедянский); в-д) известняки под люминесиентным микроскопом, увел. 62; в) мадстоун (р-н оз. Ошколь); г) вакстоун (р-н оз. Ошколь); д) пакстоун (западнее оз. Тус)

Fig. 4. Rocks impregnated with bituminous matter: a) sample with solid bitumen excretions (Kamen quarry); b) coral limestone (boundstone), impregnated with bituminous substance (Lebedyansky quarry); c-e) limestones under fluorescent microscope, zoom in 62; c) madstone (lake Oshkol area); d) wackstone (lake Oshkol area); e) packstone (west of the lake Tus)

В процессе проведения люминесцентного анализа образцов установлено, что во всех петротипах, кроме баундстоуна и пакстоуна, преобладают эпигенетичные битумоиды, состав которых изменяется от маслянистого (желтое свечение) до смолистого (буровато-коричневое свечение). Содержание эпибитумоидов во всех петротипах, кроме рифогенных и органогенных известняков, зависит преимущественно от текстурно-структурных особенностей породы и интенсивности постседиментационных преобразований. Характерными битуминозными текстурами являются пятнистые и трещинные, структуры - неравномерно и равномерно рассеянные. Установлено, что в трещинах, микростилолитовых швах, перифериях каверн присутствуют преимущественно битумоиды смолисто-асфальтенового состава (буровато-коричневое свечение), а в основной массе породы отмечаются более легкие фракции маслянисто-смолистого (буроватое свечение) и маслянистого (желтоватое свечение) состава, что свидетельствует о миграции УВ из трещин в породу.
В рифогенных (баундстоун) и органогенных (пакстоун) известняках в целом содержание битумоидов наиболее высокое, так как текстурно-структурные особенности пород обуславливают их большую пористость и проницаемость. Кроме эпигенетических в таких известняках обнаружены сингенетические битумоиды, которые равномерно пропитывают основную массу породы и характеризуются широким диапазоном состава (от маслянистого до смолистоасфальтенового).

\section{Литогеохимические инструменты реконструкции} формирования отложений

Комплексное исследование отложений геохимическими методами позволило уточнить фациальные обстановки и геохимию среды седиментогенеза $[13,14]$.

Геохимическая специализация выделенных петротипов карбонатных пород была проведена с помощью растровой электронной микроскопии и рентгеноспектрального микроанализа. 
Результаты растровой электронной микроскопии свидетельствуют о чистоте состава рифогенных (баундстоун) известняков, состоящих преимущественно из кальцита с незначительной примесью $\mathrm{Fe}, \mathrm{Mg}, \mathrm{Si}, \mathrm{S}, \mathrm{P}$ и др.

В результате рентгеноспектрального микроанализа уточнен химический состав петротипов. Так, например, химический состав пакстоуна представлен кальцитом, в котором содержится небольшое количество кремния и железа (рис. 5).

Флаутстоун содержит в примесях элементы: кремний, алюминий, кальций, магний и фосфор, но они имеют небольшое содержание в породе. Преобладающим компонентом является железо.
Вакстоун отличается высоким содержанием железа, установлено среднее значение кремния и кальция, а также минимальные значения алюминия, магния, цинка и фосфора.

Для реконструкции физико-химической и тектонической обстановки седиментогенеза с помощью масс-спектрометрии с индуктивно-вязанной плазмой (ICP-MS) были изучены образцы из разных петротипов, в каждом из которых определялись 40 химических элементов, которые нормировались к составной пробе палеозойских глинистых сланцев Северной Америки (NASC - NorthAmericanShaleComposite) $[15,16]$.

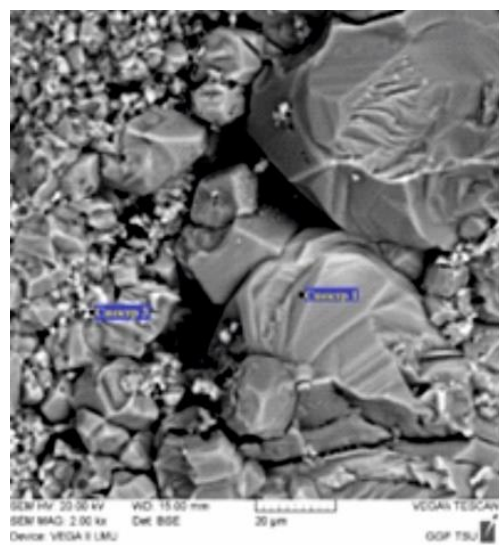

$\mathrm{a} / \mathrm{a}$

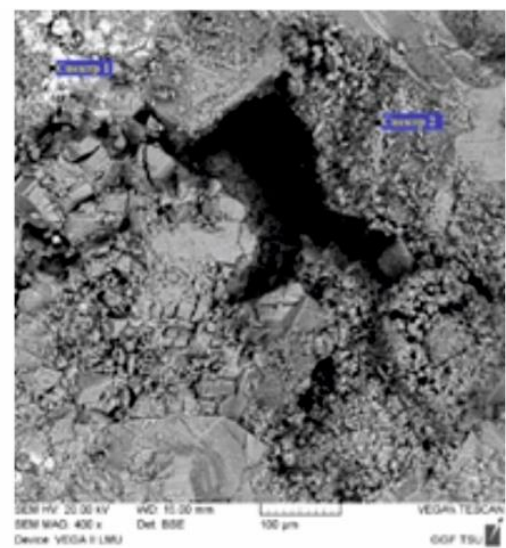

$6 / b$

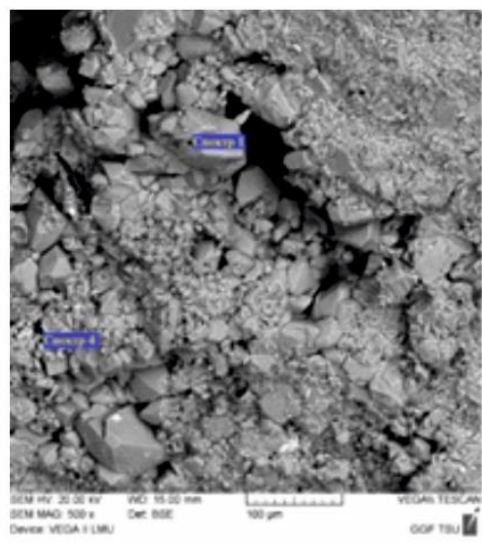

$\mathrm{B} / \mathrm{C}$

Рис. 5. Результаты рентгеноспектрального микроанализа: а) пакстоун (р-н оз. Фыркал); б) флаутстоун (р-н оз. Фыркал); в) вакстоун (р-н оз. Оиколь)

Fig. 5. Results of X-ray spectral microanalysis: a) packstone (lake Fyrkal area); b) floutstone (lake Fyrkal area); c) wackstone (lake Oshkol area)

Анализ мультиэлементных диаграмм, построенных по результатам ICP-MS, показал, что в карбонатных породах районов оз. Фыркал, Ошколь и западнее 03. Тус присутствуют редкоземельные элементы, и выявил, что условия осадконакопления были мелководно-морские.

Концентрация элементов $\mathrm{Cr}$ и $\mathrm{Ni}$ на диаграмме оказалась выше кларковых значений, содержание $\mathrm{Zn}$ близкое к кларку. На диаграмме выявлена небольшая стронциевая аномалия, которая может быть интерпретирована как признак формирования отложений в условиях крайнего мелководья $[17,18]$.

Вычисленное значение индикатора палеосолености ( $\mathrm{Sr} / \mathrm{Ba})$ [19] является доказательством морских условий осадконакопления. Известным фактом является то, что в результате процессов химического выветривания происходит совместная миграция таких элементов, как стронций и барий. Они попадают в морские водоемы, в которых барий быстро коагулируется в прибрежных условиях с $\left(\mathrm{S}_{4}\right)_{2}$ и выпадает в осадок. Стронций же осаждается только тогда, когда соленость воды достигает 15 оo.

Кроме этого, выявленная в породах цериевая аномалия $\mathrm{Ce} / \mathrm{Ce}$ * подтверждает выводы о формировании отложений в морских условиях. Установлено, что церий может окисляться и переходить в растворимую форму в условиях морского седиментогенеза, что проявлено в форме отрицательной цериевой аномалии, и значение отношения становится меньше 1 (табл. 1).

Таблица 1. Отношение $\mathrm{Sr} / \mathrm{Ba}$ как индикатора палеосолености

Table 1. Sr/Ba ratio as paleosalinity indicator

\begin{tabular}{cccccc}
\hline № образца/Sample no. & $1 \Phi-\mathrm{C}$ & $3 \Phi-\mathrm{C}$ & $4 \Phi-\mathrm{C}$ & $5 \Phi-\mathrm{C}$ & $6 \Phi-\mathrm{C}$ \\
\hline $\mathrm{Sr} / \mathrm{Ba}$ & 43,34 & 27,83 & 19,3 & 20,63 & 14,7 \\
\hline Ce/Ce* & 0,24 & 0,18 & 0,16 & 0,22 & 0,3 \\
\hline
\end{tabular}

Для уточнения состава карбонатных пород рентгенофлуоресцентным методом изучены образцы с Северной Хакасии. По результатам применения этого метода построена диаграмма для карбонатных пород $\mathrm{MgO}-\mathrm{CaO}$. Все фигуративные точки исследуемых пород находятся в зоне собственно известняков или доломитовых известняков. Кроме этого, был подсчитан индикатор положения осадков на фациальном профиле $\mathrm{Fe} / \mathrm{Mn}$. Анализ результатов $(25,47 \ldots 44,54)$ свидетельствует об относительно мелководном морском режиме осадконакопления (табл. 2).

Таблица 2. Соотномение Fe/Mn

Table 2. Fe/Mn ratio

\begin{tabular}{ccccc}
\hline № образца/Sample no. & $0 Ф-\mathrm{C}$ & $5 \Phi-\mathrm{C}$ & $\mathrm{O}-01 \mathrm{~K}$ & Т-12K \\
\hline $\mathrm{Fe} / \mathrm{Mn}$ & 28,25 & 43,9 & 25,47 & 44,54 \\
\hline
\end{tabular}




\section{Заключение}

Палеореконструкция живетских карбонатных отложений в пределах АCСО на основе комплекса методов палеонтологических и литогеохимических исследований позволила выявить особенности палеосреды осадконакопления, благоприятной для аккумуляции ОВ, захоронения и генерации УВ.

В изученных обнажениях были обнаружены окаменелости, датирующие возраст отложений как живетский (брахиоподы Acrospirifer cheehiel K., кораллы Thamnopora cervicornis В. и др.). Бассейн седиментации характеризовался условиями нормально-соленого теплого, морского мелководья. На некоторых участках бассейна шло формирование рифогенных построек (территория карьеров Камень, Подломский, Лебедянский), в некотором удалении от береговой линии, без привноса терригенного материала, о чем свидетельствуют стенобионтные кораллы.

Это также подтверждается расчетом индикаторов палеосолености (Sr/Ba: 43, 34... 14,7), палеогеографической позицией отложений в пределах бассейна седиментации $\mathrm{Ce} / \mathrm{Ce}^{*}(0,16 \ldots 0,24)$, положения осадков на фациальном профилеFe/Mn $(28,25 \ldots 44,54)$ [19].

В отложениях живетского яруса изученных районов выделены шесть петротипов карбонатных пород: баундстоун, мадстоун, вакстоун, пакстоун, флаутстоун и рудстоун.

Породы интенсивно изменены постседиментационными процессами: перекристаллизацией с укрупнением зерен, микростилолитизацией, окремнением, доломитизацией и выщелачиванием, что способствовало образованию трещин, пор и каверн. Эти преобразования имеют влияние на приобретение фильтрационно-емкостных свойств данных известняков.

\section{СПИСОК ЛИТЕРАТУРЫ}

1. Нефтегазоперспективные объекты палеозоя Западной Сибири сейсмогеологические модели эталонных месторождений / В.А. Конторович, Л.М. Калинина, А.Ю. Калинин, М.В. Соловьев // Геология нефти и газа. - 2018. - № 4. - С. 5-15.

2. Геология и минерагения Северной Хакасии / Ю.С. Ананьев, Б.Д. Васильев, С.С. Гудымович, И.И. Коптев, Н.А. Макаренко, В.П. Парначев, С.В. Парначев, М.Г. Танзыбаев, А.Ю. Фальк. Томск: ТПУ, 2006. - 238 с

3. Конторович В.А., Калинина Л.М. Геологическое строение и нефтегазоносность палеозоя Западной Сибири, модели эталонных месторождений // Бурение и нефть. - 2019. - № 11. C. $18-25$.

4. Лобова Г.А., Лунёва Т.Е., Исаева О.С. Нефтегазоносность коры выветривания и палеозоя Колтогорского мезопрогиба (северо-запад Томской области) // Известия Томского политехнического университета. Инжиниринг георесурсов. - 2019. T. 330. - № 9. - C. 103-113.

5. Embrym A.F., J.E. Klovan A late Devonian reef tract on north heastehn Bancks Island Northwest Territories // Bulletin of Canadian Petroleum Geology. - 1971. - V. 19. - № 4. - P. 730-781.

6. Longman M.W. Carbonate diagenetic textures from nearshore diagenetic environments // AAPG. Bulletin. - 1980. - V. 64. № 4. - P. 461-487.

7. Ржонсницкая М.А. Полевой атлас характерных комплексов фауны и флоры девонских отложений Минусинской котловины. - М.: Госгеолтехиздат, 1955. - 140 с.

8. Уилсон Дж.Л. Карбонатные фации в геологической истории. М.: Недра, 1980. - 463 с.
Наибольшее количество битумоидов зафиксировано в рифогенных известняках-баундстоун. Этот петротип обладает высоким коллекторским потенциалом, т. к. слагающие его кораллы обладают хорошими для этого качествами - кавернозностью и биопустотностью.

В рифогенных и органогенных известняках кроме макрофаунистических остатков присутствовала водорослевая органика, фито- и зоопланктон, преобразованные в дальнейшем в сингенетично-битуминозное вещество. Наличие сингенетично-битуминозного вещества и ореольных структур в рифогенных и органогенных известняках свидетельствует не только о миграции УВ, но и об их генерации.

Остальные петротипы содержат эпигенетичные битумоиды, что зависит преимущественно от текстурно-структурных особенностей породы и интенсивности постседиментационных преобразований. Характерные битуминозные текстуры трещинные и пятнистые. Структуры неравномерно рассеянные, реже равномерно рассеянные. Состав битумоидов преимущественно маслянисто-смолистый и асфальтеновый. Остаточный характер битумоидов указывает на миграцию легких фракций в зоны разуплотнения.

Результаты исследований позволили выявить горизонты в пределах АССО (а именно, в районах карьеров Камень, Подломский, Лебедянский, оз. Фыркал, Ошколь и западнее о3. Тус), которые, являясь коллекторами порово-трещинного типа, при наличии хороших покрышек и отсутствии глубокой эродированности территории могли формировать залежи УВ.

Использование результатов проведенных исследований позволяет существенно расширить представления на условия формирования аналогичных пород фундамента Западной Сибири [20, 21].

9. Danham R.J., Ham W.E. Classification of carbonate rocks according to depositional texture Classification of carbonate rocks // Symposium American Association of Petroleum Geologists. 1962. - V. 1. - P. 108-121.

10. Kuramshin R.M., ChernitskiyA.V., Gula E.V. Differential estimation of oil reserves based on carbonate reservoir classification (Russian) // Нефтяное хозяйство. - 2019. - № 5. C. $48-50$.

11. Юдович Я.Э. Проблема геохимической диагностики фации седиментогенеза. - Томск: ТГУ, 2007. - 188 с.

12. Scholle P.A., Ulmer-Scholle D.S. Color guide to the petrography of carbonate rocks: grains, textures, porosity, diagenesis // AAPG. Memour 77, Tulsa, 2003. - 474 p.

13. Кузьмин В.А. Цифровая формализация микроструктурных параметров карбонатных коллекторов на основе Фурьеанализа // Актуальные проблемы нефти и газа. - 2018. Вып. 1 (20). - С. 1-15.

14. Рид С.Дж.Б. Электронно-зондовый микроанализ и растровая электронная микроскопия в геологии. - М.: Техносфера, 2008. $-232 \mathrm{c}$

15. Haskin M.A., Haskin L.A. Rare earths in European shales: a redetermination // Science. - 1966. - V. 154. - P. 507-509.

16. Rare earth elements in Japan Sea sediments and diagenetic behaviour of Ce/Ce*: results / P.W. Murray, M.R. Buchholtzten, H.J. Brumsack, D.C. Gerlach, G.P Russ // Geochimica et Cosmochimica Acta. - 1991. - V. 55. - P. 2453-2466.

17. Bjorlikke K. Sedimentology and petroleum geology. - Berlin: Springer, 1989. $-363 \rho$.

18. Tucker M.E., Wright V.P., Dickson J.A. Carbonate Sedimentology. - Oxford: Blackwell, 1990. - 482 p. 
19. Immenhauser A. Towards a definition of the deep burial realm in carbonate diagenesis // 34th International Meeting of Sedimentologists: abstract book. - Rome, 2019. - P. 1170.

20. Domanic type deposits - target object of prospecting works (Russian) / S.V. Bagmanova, P.V. Pankratiev, I.V. Synkova, A.S. Stepanov, A.V. Kolomoets // Нефтяное хозяйство. - 2018. № 12. - C. 92-96.
21. Новые данные о специфических условиях формирования турнейских отложений Колывань-Томской складчатой зоны / М.И. Шаминова, А.А. Поцелуев, И.В. Рычкова, Я.Ю. Корчуганов // Известия Томского политехнического университета. Инжиниринг георесурсов. - 2016. - Т. 327. - № 3. - С. 16-22.

Поступила 23.06.2021 2.

\section{Информация об авторах}

Шаминова М.И., кандидат геолого-минералогических наук, доцент отделения геологии Инженерной школы природных ресурсов Национального исследовательского Томского политехнического университета.

Рычкова И.В., кандидат геолого-минералогических наук, доцент отделения геологии Инженерной школы природных ресурсов Национального исследовательского Томского политехнического университета.

Caар K.H., геолог 1 категории АО «Якутскгеология» Алданское ОП. 
UDC 553,98; 551,8: 551.734.3: $551.243 .31(235,223)$

\title{
PALEOGEOGRAPHIC, LITHOLOGICAL-GEOCHEMICAL FEATURES AND BITUMINITY OF ZHIVETIAN DEPOSITS OF THE MIDDLE DEVONIAN OF THE ALTAI-SAYAN FOLDED REGION
}

\author{
Marina I. Shaminova1, \\ mshaminova@mail.ru \\ Irina V. Rychkova ${ }^{1}$, \\ irina.rychkova@mail.ru \\ Kristina N. Saar2, \\ saar.kris@mail.ru \\ ${ }_{1}^{1}$ National Research Tomsk Polytechnic University, \\ 30, Lenin avenue, Tomsk, 634050, Russia. \\ 2 «Yakutskgeologiya» Aldan OP, \\ 24, Kalvitsyna avenue, Yakutsk, 677009, Russia.
}

The relevance of the research is caused by insufficient knowledge on the Paleozoic oil and gas deposits of Western Siberia and the AltaiSayan folded region associated with it, although new oil and gas condensate fields have recently been discovered in this territory. Paleozoic deposits are highly promising objects for discovery of hydrocarbon deposits. The results of paleogeographic and lithological-geochemical studies of the region under study can significantly affect the reconstruction of paleoenvironments favorable for generation and accumulation of hydrocarbons, as well as assessment of the prospects for oil and gas potential of Paleozoic sediments and identification of unconventional reservoirs.

Objects: carbonate deposits of the Zhivetian stage of the Middle Devonian, outcropping in the quarries Kamen and Podlomsk (Tomsk region), Lebedyansky quarry (Kemerovo region), in the areas of Lake Fyrkal and Oshkol, as well as west of the lake Tus (Northern Khakassia).

Purpose: paleogeographic reconstruction of sedimentation environments favorable for oil and gas accumulation, as well as identification and assessment of the prospects for oil and gas potential of Paleozoic sediments in the rocks of the Paleozoic basement.

Methods: lithological-petrographic, paleontological, paleogeographic, lithogeochemical (X-ray spectral, scanning electron microscopy, luminescence microscopic, inductively coupled plasma mass spectrometry (ICP-MS)).

Results. The authors were the first to establish signs of oil and gas content of the Middle Devonian deposits in the Tomsk region (Kamen and Podlomsky quarries), in the Kemerovo region (Lebedyansky quarry), in Northern Khakassia (areas of Lake Fyrkal and Oshkol, as well as west of Lake Tus). As a result of paleontological and geochemical studies, the features of the paleoenvironment of sedimentation, favorable for accumulation of OM, burial and generation of hydrocarbons, have been revealed. Among the studied sediments, the petrotypes: boundstone, rudstone, floutstone, packstone, wakstone and mudstone, which underwent intensive postsedimentary transformations, significantly influenced their reservoir properties, were identified. Luminescence microscopic studies made it possible to establish the facts of intensive fluid migration in the studied areas and to identify potential reservoirs. It was found that the largest amount of bitumoids is recorded in reef boundstone limestones. This petrotype has a high reservoir potential, because the corals composing it have good qualities for this cavernousness and biowasiness.

\section{Key words:}

Altai-Sayan fold area, Zhivetian deposits, Middle Devonian, bituminous content, petrotypes.

\section{REFERENCES}

1. Kontorovich V.A., Kalinina L.M., Kalinin A.Yu., Solovyev M.V. Oil and gas targets of the Paleozoic Deposits of Western Siberia seismogeological models of reference fields. Geology of Oil and Gas, 2018, no. 4, pp. 5-15. In Rus.

2. Ananyev Yu.S., Vasilev B.D., Gudymovich S.S., Koptev I.I., Makarenko N.A., Parnachev V.P., Parnachev S.V. Tanzybaev M.G., Falk A.Yu. Geologiya i minerageniya Severnoy Khakasii [Geology and Minerageny of Northern Khakassia]. Tomsk, TPU Publ., 2007. $236 \mathrm{p}$.

3. Kontorovich V.A., Kalinina L.M. Geological structure and oil and gas content of the Paleozoic of Western Siberia, models of reference fields. Drilling and oil, 2019, no. 11, pp. 18-25. In Rus.

4. Lobova G.A., Luneva T.E., Isaeva O.S. Oil and gas content of the weathering crust and Paleozoic of the Koltogorsk mesotrough (north-west of the Tomsk region). Bulletin of the Tomsk Polytechnic University. Geo Assets Engineering, 2019, vol. 330, no. 9, pp. 103-113. In Rus.

5. Embrym A.F., Klovan J.E.A late devonian reef tract on north heastehn Bancks Island Northwest Territories. Bulletin of Canadian Petroleum Geology, 1971, vol. 19, no. 4, pp. 730-781.
6. Longman M.W. Carbonate diagenetic textures from nearshore diagenetic environments. AAPG. Bulletin, 1980, vol. 64, no. 4, pp. 461-487.

7. Rzhonsnitskaya M.A. Polevoy atlas kharakternykh kompleksov fauny i flory devonskikh otlozheniy Minusinskoy kotloviny [Field atlas of characteristic assemblages of fauna and flora of the Devonian deposits of the Minusinsk depression]. Moscow, Gosgeoltekhizdat Publ., $1955.140 \mathrm{p}$.

8. Wilson J.L. Karbonatnye fatsii v geologicheskoy istorii [Carbonate facies in geological history]. Moscow, Nedra Publ., 1980. 463 p.

9. Danham R.J., Ham W.E. Classification of carbonate rocks according to depositional texture Classification of carbonate rocks. Simposium American Association of Petroleum Geologists, 1962, vol. 1, pp. 108-121.

10. Kuramshin R.M., Chernitskiy A.V., Gula E.V. Differential estimation of oil reserves based on carbonate reservoir classification (Russian). Neftaynoe khozayistvo, 2019, no. 5, pp. 48-50. In Rus.

11. Yudovich Ya.E. Problema geokhimicheskoy diagnostiki fatsi i sedimentogeneza [The problem of geochemical diagnostics of the sedimentogenesis facies]. Tomsk, TSU Publ., 2007. 188 p.

12. Scholle P.A., Ulmer-Scholle D.S. Color guide to the petrography of carbonate rocks: grains, textures, porosity, diagenesis. $A A P G$. Memour 77, Tulsa, 2003. 474 p. 
13. Kuzmin V.A. Digital formalization of microstructural parameters of carbonate reservoirs based on Fourier analysis. Actual problems of oil and gas, 2018, vol. 1 (20), pp. 1-15. In Rus.

14. Reed S.G.B. Elektronno-zondovy mikroanaliz i rastrovaya elektronnaya mikroskopiya $v$ geologii [Electron probe microanalysis and scanning electron microscopy in geology]. Moscow, Tekhnosfera Publ., 2008. 232 p.

15. Haskin M.A., Haskin L.A. Rare earths in European shales: a redetermination. Science, 1966, vol. 154, pp. 507-509.

16. Murray P.W., Buchholtzten M.R. Rare earth elements in Japan Sea sediments and diagenetic behaviour of $\mathrm{Ce} / \mathrm{Ce} *$ : results. Geochimica et Cosmochimica Acta, 1991, vol. 55, pp. 2453-2466.

17. Bjorlikke K. Sedimentology and petroleum geology. Berlin, Springer, 1989. $363 \rho$

18. Tucker M.E., Wright V.P., Dickson J.A. Carbonate sedimentology. Oxford, Blackwell, 1990. 482 p.

Information about the authors
19. Immenhauser A. Towards a definition of the deep burial realm in carbonate diagenesis. 34th International Meeting of Sedimentologists. Rome, 2019. p. 1170.

20. Bagmanova S.V., Pankratiev P.V., Synkova I.V., Stepanov A.S., Kolomoets A.V. Domanic type deposits - target object of prospecting works (Russian). Neftaynoe chozayistvo, 2018, no. 12, pp. 92-96. In Rus.

21. Shaminova M.I., Potseluev A.A., Rychkova I.V., Korchuganov Ya.Yu. New data on specific conditions of formation of tournaisian deposits of Kolyvan-Tomsk folded zone. Bulletin of the Tomsk Polytechnic University. Geo Assets Engineering, 2016, vol. 327, no. 3, pp. 16-22. In Rus.

Received: 23 June 2021.

Marina I. Shaminova, Cand Sc., associate professor, National Research Tomsk Polytechnic University.

Irina V. Rychkova, Cand Sc., associate professor, National Research Tomsk Polytechnic University.

Kristina N. Saar, 1 category geologist, AO «Yakutskgeologiya» Aldan OP. 